\title{
Aceh Cultural Elements in the Settlement Context
}

\author{
Destri Wulanda, Happy Ratna Santoso, and Dewi Septanti \\ Department of Architecture, Institut Teknologi Sepuluh Nopember, Surabaya \\ e-mail: happy_rs@arch.its.id
}

\begin{abstract}
Abstrak-Indonesia consists of various diverse tribes and cultures. Culture is the result of people's thoughts and behavior. Culture can also act as the identity of a tribe that has its characteristics. The difference in characteristics is interesting to study, one of which is the culture of Aceh in Indonesia. Aceh is rich in cultural values and customs because of its historical background. Influences from various backgrounds eventually shaped the characteristics of Acehnese. The culture of Aceh has been discussed in several studies, but no one has focused on the context of settlement. Therefore, this study was conducted to analyze aspects of Aceh's culture in a settlement. Cultural aspects can be analyzed based on world views, values, manifestations, activity systems, and social expressions. This study is a literature review, which uses secondary data to answer the research objectives. Secondary data were obtained from literature related to research topics, such as books, journals, regulations, etc. Furthermore, the data collected will be analyzed and concluded using descriptive analysis. The study results explain that every aspect of Aceh's culture refers to Islamic rules, where the balance between customary law and religious law is important for Acehnese lives.
\end{abstract}

Kata Kunci-Cultural Characteristic, Settlement, Social Expression.

\section{INTRODUCTION}

A $\mathrm{CEH}$ is one of the provinces in Indonesia which is rich in culture and customs. Settlement in Aceh influenced by the culture of the community, where the community highly values its cultural and religious values. Interaction between people and the environment forms the characteristics of the settlement. Culture in society will grow naturally, which can be seen from the activities, behavior, and results of their work [1]. Furthermore, culture is part of science, belief, art, morals, law, customs, and habits of humans [2] . Every cultural and social aspect of the community will affect their residential environment.

The magnitude of the influence of Islam's religion and culture has made Aceh called the Veranda of Mecca or Seramoe Mekkah. This cultural influence creates a close relationship between religious law and customary law in community life, which affects the characteristics of settlements. At present, studies related to Aceh Culture have been discussed in several contexts, but none have focused on settlement context. Therefore, this study aims to explain the culture of Aceh in the context of housing and settlements. This study will focus on analyzing the cultural components seen in Figure 1. The arrows in the images that increasingly lead to the right are more specific cultural components, starting from world views, which refer to values and lead to lifestyles, and the most specific is activity systems. While, the more concrete one is reviewed based on social expressions, consist of kinship, family structure, roles, social networks, identity, institutions, and others [3].

\section{METHOD}

This study is a literature review related to Aceh culture. The aspects studied are based on cultural and social. The culture expressions consist of world view, values, lifestyle, and activity system. While the social aspects of kinship, kinship, family structure, rules, status, identity, and institutions. Literature sources can include books, journals, proceedings, regulations, and policies. The collection of literature is then reduced and summarized in the description.

\section{RESULT AND DISCUSSION}

This research will discuss the component of Aceh Culture in a residential environment. Aceh's cultural expressions that more specifically affect settlements will be analyzed based on world views, values, lifestyles, and activity systems. Furthermore, concrete culture is analyzed based on social expressions, such as kinship, family structure, rules, status, identity, and institutions.

\section{A. Culture Experessions}

The cultural component can influence the condition of a built environment, where lifestyle and activity systems are the most influential components in designing the environment. More specific cultural expressions consist of world views, values, lifestyles, and activity systems [3].

\section{1) World Views}

World views are views about life, the world, and humanity. World views are too abstract and difficult to use in expressing culture [3]. The people of Aceh have a world view of the life of customary law and religion law must not be separate, must be in harmony and balance between these laws [4]. Management of a village in Aceh is inseparable between traditional and religious leaders. Tengku Meunasah (religious leaders) play the role of people who take care of everything related to religious law in a village. Geuchik is a person who plays a role in running the government.

\section{2) Values}

Values are one aspect of world views. Specifically, it is often explained through ideas, images, schematics, meanings, and will then lead to norms, standards, rules, and expectations [3]. Acehnese is guided by norms and Islamic teachings. Community life patterns are limited by law and customs ('urf) [4]. ' $U r f$ is a custom according to shari'ah. If there are people who act out of tune, they will be subject to sanctions that have 
The $6^{\text {th }}$ International Seminar on Science and Technology (ISST) 2020

July $25^{\text {th }}$ 2020, Institut Teknologi Sepuluh Nopember, Surabaya, Indonesia
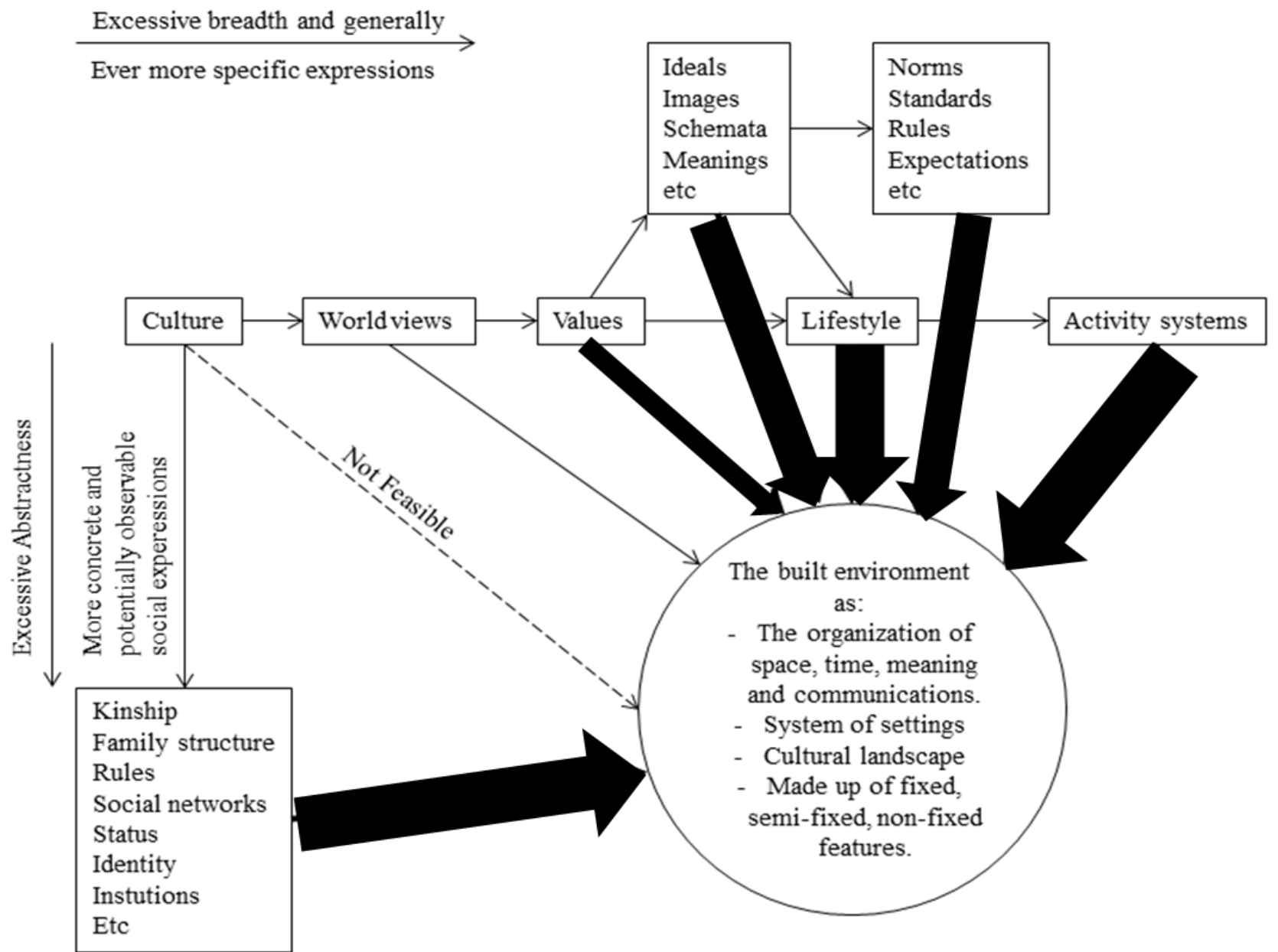

Figure. 1. Effect of Cultural Components on the Built Environment.

been set, where the aim is to regulate people's lives and be a reflection of the personality of an ethnic group.

\section{3) Lifestyles}

Life styles are part of human choices and needs that are more general than activity systems. Age, gender, race, ethnicity, religion, education, work, etc., can represent life styles. In addition, life styles are widely used as marketing, advertising, and housing design tactics by developers [3]. In addition, lifestyle is how the individual's life is identified by how to spend time (activity), interest in something and opinions about things in the surrounding environment [6]. Law and customary norms that are integrated with Islam are a way of life for the people of Aceh and will continue to develop throughout history. So Islam is the basis of Aceh's culture in the patterns of community life [6]. Society applies the concept of halal lifestyle or Islamic lifestyle, which is a habit of the community in their daily lives to move, consume, utilize and use goods and services that do not conflict with the values and principles of Islamic religion [7].

\section{4) Activity Systems}

Activity systems are the most concrete cultural expressions, where architects usually use activity analysis in designing an environment. Furthermore, seeing the latent aspects of activities is very important and sometimes influences the design and function of space [3]. The community has a good relationship between neighbors and a high level of solidarity. This matter can be visible from how the social activities carried out regularly, such as when one community member organizes an event, the neighbors will participate and help organize the event. As for daily activities, the community generally works from morning to evening. In the afternoon, they will spend time with family and neighbors. Furthermore, when it is time for worship, the community will go to the meunasah to carry out their duties, especially during Maghrib and Friday prayers. All activities will stop for a moment at worship time, shops and public areas will be closed temporarily[4].

\section{B. Social Expressions}

Cultural elements are also be analyzed through social expressions which are the most concrete parts and have the potential to be observed, consisting of kinship, family structure, rules, status, identity, institutions, etc. [3].

\section{1) Kinship}

Kinship is a family relationship through marriage ties because it has blood relations, both relationships in one family or relationships between other families [8]. Kinship in the Aceh community generally adheres to the patrilineal principle, where the flow of offspring originates from the father's side [8]. This matter can be seen from the status of the child if one parent has died. If the mother dies, the father is responsible for his child. But if the father dies, the mother is not responsible, but a sibling on the father's side. Mother's 
The $6^{\text {th }}$ International Seminar on Science and Technology (ISST) 2020

July $25^{\text {th }} 2020$, Institut Teknologi Sepuluh Nopember, Surabaya, Indonesia

siblings don't have responsibilities for heredity because it is considered weak in terms of law and tradition. A father respected by family members. Usually, the child is closer to the mother because he is reluctant with his father. All problems in the family not delivered through his father, but always through his mother. In Acehnese, all small matters are taken care of by the mother, except when those matters require the attention of a father [9].

\section{2) Family Structure}

Family structure is based on the role of family members and their relationship patterns. Examples include the role of women in the family as wives, daughters-in-law, and mothers. Then the pattern of relationships in family members will form the structure of roles in the family. The family structure consists of [10]: (1)The Nuclear family consists of husband, wife, and children in a house. (2) The dyad family is a family consisting of husband, wife, and does not have children who live together. (3) An elderly couple consisting of husband and wife who is old with a child who lives apart from their parents, (4) The childless family is a family that does not have children due to various factors, such as being married late. (5) The extended family is a family that consists of several generations and lives together in one house, (6) The single-parent family consists of one parent, either father or mother, and child, which occurs due to divorce and death. (7) Kin-network family consists of several nuclear families living in one house or nearby. Besides, family members also share the same goods and services, such as bathrooms, kitchens, bathrooms, televisions, and others. (8) The blended family is a widower or widow who remarries and raises a child from a previous marriage. (9) The single adult family is a family consisting of adults who live alone due to divorce or death. (10) Multigenerational families are families with several generations living together in one house. In general, the family system of the Acehnese community follows the nuclear family system. This system is part of a small family consisting of father, mother, and children. When a child is married, the child has he right to build a household as a nuclear family[9].

\section{3) Roles}

Roles consist of the role of leader, and the individuals in society and family [11]. The role of a leader is demanded to be an example for its members following the norms and rules according to their position. Furthermore, individuals who influence the community, such as the village government and public figure. Leaders must be wise and responsible to set an example for others. Then the role of individuals for the family, such as husband, wife, children, and the community.

Roles consist of the role of leader, and the individuals in society and family [11]. The Acehnese leaders consisted mainly of Geuchik and Tuha Peut. Geuchik is the village head who is responsible for managing village affairs. Tuha Peut is a village advisory body that has a role in monitoring the performance and decisions of the village head and has the authority to make decisions [12]. Furthermore, the role of individuals in the community also influences patterns of life in settlements in Aceh, such as the role of Tengku Meunasah to take care of everything related to religious matters in a village [4].

The role of individuals in the family is divided based on the roles of father, mother, and child [11]. The father acts as the head of the family, which is responsible for being the husband and father of his child. Father served as a breadwinner, educator, and protector for his family. Whereas in the family, the mother acts as the wife and mother of her children. Mothers have the task of taking care of her husband and child, and sometimes can help husbands earn extra income. Furthermore, the child acts according to the stage of development, both physically, mentally, socially, and spiritually. Every family member also participates as a member of the community.

\section{4) Status}

Social status in society is divided based on economic status, social status, and political status [9]. Generally, the status of people in Aceh's settlements is undifferentiated, because the community considers that each community has the same rights and obligations. Between communities have a good relationship, where they have a high sense of solidarity. Nevertheless, in political status, the community is divided based on the position they have to regulate and manage a settlement. In the political status of the Acehnese people must be balanced between the government and religious leaders so that people's lives in the settlements are arranged following established regulations.

Status is an embodiment or reflection of the rights and obligations of individuals in their behavior. Social status is often also referred to as the position or position, the rank of someone in the community. Every individual in society has a social status which is divided into economic status (very rich, rich and poor), social status (based on caste or title), and political status (executive, legislative and judicial officials) [11].

Furthermore, the social status of the community is divided into descendants of the king, Ulee Balang, scholars, and ordinary people [9]. The king's descendants are considered as the most elite status and at this time respect for the king's descendants is still seen in the neighborhoods, as special calls to male offspring are called Ampons and women are called Cutnyak [8]. While Ulee Balang is commander in chief and under the control of the Sultan/ king as his representative to lead small territories [14]. Furthermore, religious leader in Acehnese play an important role both in the social, religious, and even in some places also play a political role. In Aceh, they are called "Teungku" or religious leaders who have gone through a process of learning from various Islamic boarding schools or pesantren to explore their knowledge [14].

\section{5) Identity}

Social identity is the knowledge that is owned by a community group that can be considered as an identity to introduce the group [15]. The identity of the people of Aceh is inseparable from Islamic laws. Even the government system in Aceh presents both elements of "Geuciek and Tengku" as community leaders, in which Islamic law must always be obeyed by every community because there are consequences 
The $6^{\text {th }}$ International Seminar on Science and Technology (ISST) 2020

July $25^{\text {th }} 2020$, Institut Teknologi Sepuluh Nopember, Surabaya, Indonesia

if the community violates the stipulated provisions [16].

\section{6) Institution}

Institution or social institutions in settlements in Aceh consist of family institutions, educational institutions, religious institutions, economic institutions, and political institutions [17]. Family institutions consist of a nuclear family (father, mother, and child) and extended family (nuclear family and relatives). In settlements in Aceh generally, there are various educational institutions, ranging from PAUD, kindergarten, elementary, junior high, to high school. Religious institutions such as Meunasah and pesantren are used by the community as a place to explore Islam. Furthermore, in Aceh, there are also economic institutions such as places of production and distribution of goods and services, as well as political institutions consisting of governments (Geuchik, Tuha Peut, etc.) and religious leaders (Tengku Meunasah).

\section{CONLUSION}

There are several aspects to analyzing cultural elements in a settlement. Culture can be analyzed through expressions from the most general to the most specific, which consists of world views, which refers to values, where values will lead to lifestyles and activity systems in a settlement. After analyzing culture in a more specific, culture can also be analyzed based on a social expression, which is the most concrete part of the potential to be observed. The social expression consists of kinship, family structure, rules, status, identity, and institutions in a residential environment.

The culture of Aceh is synonymous with traditional law which is guided by Islamic norms. Customary law and religious law have the same influence on people's lives and can't be detached from each other, wherein the system of governance in a village consists of Geuchik as officials who take care of customary law in the village government, while Tengku Meunasah as officials who take care of everything related to religion. Everything in the Aceh environment is regulated in customs so that the lifestyles and behavior of the people follow Islamic law. If the community does not follow the rules that have been made, they will get a penalty following applicable customary law.

The social expression of the Acehnese people is related to the kinship system, family structure, roles, status, identity, and institutions that were formed from the customs of the community from the past and still exist today. This can be seen from the kinship system that adheres to the patrilineal principle, which follows the lineage of the male side. The family structure of the community consists of father, mother, and child, which have their respective roles in the family. furthermore, the social status of the Acehnese people has been divided since time immemorial, such as descendants of the king, Ulee Balang, scholars, and ordinary people. The descendants of the king in Aceh are still respected to this day, seen from a special call from the community. Ampon is a call for boys and Cutnyak for girls.

\section{REFERENCES}

[1] D. Rahmadaniyati, "Budaya Bahari sebagai Landasan Peremajaan yang Berkelanjutan pada Perumahan Nelayan di Atas Air," Inst. Teknol. Sepuluh Nop., 2017.

[2] N. H. Kistanto, “Tentang Konsep Kebudayaan,” Kaji. Kebud., vol. 10, hal. 1-11, 2015.

[3] A. Rapoport, Culture, Architecture, and Design. USA: Locke Science Publishing Company, 2005.

[4] M. Kurdi, Aceh Dimata Sejarawan. Banda Aceh: Lembaga Kajian Agama dan Sosial, 2009.

[5] R. Plummer, Life Span Development Psychology: Personality and Sociolization. New York: Academic Press, 1983.

[6] A. Nurdin, "Revitalisasi Kearifan Lokal di Aceh: Peran Budaya dalam Menyelesaikan Konflik Masyarakat," Analisis, vol. XIII, no. 1, hal. 135-154, 2013.

[7] H. H. Adinugraha dan A. H. A. Ulama'i, "Halal Lifestyle di Indonesia," Ani-Nisbah J. Ekon. Syariah, vol. 5, no. 2, 2019.

[8] A. N. Jamaluddin, "Sistem Kekerabatan Masyarakat Kampung Sawah di Kota Bekasi,” el Harakah, vol. 17, no. 2, hal. 259-274, 2015.

[9] I. Alfian, Syamsuddin, H. Husin, M. N. Abbas, M. I. Sulaiman, dan R. Umar, Adat Istiadat Daerah Propinsi Daerah Istimewa Aceh. Departemen Pendidikan dan Kebudayaan, 1986.

[10] N. Halme, P. Astedt-Kurki, dan M.-T. Tarkka, "Fathers' Involvement with their Preschool-age Children: How Fathers Spend Time with Their Children in Different Family Structures," Child Youth Care Forum, no. May, 2009.

[11] A. Heriyanto C, Kelas sosial, status sosial, peranan sosial dan pengaruhnya, Modul Sos. 2017.

[12] Pemerintah Desa Lubuk Sukon, "Rencana Pembangunan Jangka Panjang Menengah Gampong Tahun 2016-2021," Aceh Besar, 2016.

[13] M. Hetharia, R. A. Zain, A. P. Saifulloh, B. Utami, E. Kustiati, dan L. Khoirunnisaa, "Makalah keluarga," Bandung, 2016.

[14] Muhammaddar, "Kedudukan Ulama dan Uleebalang sebagai Elit Sosial Politik Aceh ( 1900-1946)," Medan, 2014.

[15] F. N. H. Utami dan B. Y. Silalahi, "Hubungan antara identitas sosial dan konformitas pada anggota komunitas virtual kaskus regional depok," in PESAT (Psikolohi, Ekonomi, Sastra \& Teknik Sipil), 2013, vol. 5, hal. 8-9.

[16] Buwaizhi, R. Iswari, dan A. Luthfi, "Ekspresi Identitas Keacehan dalam Interaksi Sosial ditengah Lingkungan Non-Syariat Islam," Fak. Ilmu Sos., 2017.

[17] K. Martina K, "Interaksi Sosial dan Institusi Sosial,” Jakarta, 2011. 